\title{
Sin necesidad de ruinas: el colmillo del elefante de Bernini
}

Pablo Manuel Millán-Millán | Escuela Técnica Superior de Arquitectura, Universidad de Sevilla

URL de la contribución <www.iaph.es/revistaph/index.php/revistaph/article/view/3859>

"Las ruinas proporcionan el incentivo para la restauración y para el retorno a los orígenes. Tiene que producirse -en nuestro nuevo concepto de historia- un itinerario de muerte o rechazo antes de que pueda haber renovación y reforma. El viejo orden tiene que morir antes de que pueda nacer de nuevo el paisaje. Muchos de nosotros conocemos el goce y emoción no tanto de crear algo nuevo, como de redimir lo que ha sido descuidado, y esta excitación es particularmente fuerte cuando la condición original es vista como sagrada o hermosa. La vieja granja tiene que decaer antes de que podamos restaurarla para llevar un estilo de vida alternativo en el campo; el paisaje tiene que ser saqueado y estropeado antes de que podamos restaurar el ecosistema natural; el barrio tiene que ser uno marginal antes de que podamos redescubrirlo y gentrificarlo. Este es el modo como producimos el esquema cósmico y corregimos la historia" (BRINCKERHOFF, 2012).

Recientemente publicaba Brinckerhoff este fragmento en un artículo sobre la necesidad del pasado cosificado en la ruina. No puedo estar más en desacuerdo con su contenido, pero al releerlo denotaba cierta calma intelectual, una sensación imposible e impensable en el debate contemporáneo sobre el patrimonio. Quizá esa sensación viniera alentada por la certeza que el autor muestra sobre el fundamento teórico y la razón de ser del hecho patrimonial. Y es que si hay algo claro en el actual debate sobre el objeto patrimonial, es una profunda ausencia de certezas. En el amplio espectro delimitado entre F. Choay con su justificación utilitarista de los elementos históricos en la ciudad actual y S. Marchan con su descripción de los hitos materiales frente a los virtuales, subyace un discurso común: el fuerte impacto del mercado en la definición del objeto patrimonial.

La necesidad o no de ruinas vendrá dada tanto en cuanto se inserte en un discurso en muchos casos ya preestablecido. En este sentido la contemporaneidad vive en cierta amnesia sobre los hechos sociales llevados a cabo por la colectividad y de vez en cuando mira al patrimonio buscando en él la excepcionalidad, no el continuum que implica el día a día. Esa razón de ser de lo cotidiano queda plasmada en la realidad material de nuestras ciudades históricas de forma humilde y senciIla, como en casas, utensilios, mobiliario, etc., y rehúye de los monumentos y de las grandes manifestaciones.

Con las agresivas puestas en valor a las que hemos sometido a nuestras ciudades centramos la atención en la excepción más que en lo cotidiano, relegando lo realmente configurador a mera anécdota, o incluso haciéndolo desaparecer. Fijar la atención en el monumento frente a la sociedad que lo generó evidencia una pérdida de memoria y de compromiso irreparable. El patrimonio requiere de sobriedad y sencillez como ejercicio de respeto frente al pasado.

"Existe una cita secreta entre las generaciones que fueron y la nuestra. Y como a cada generación que vivió antes que nosotros, nos ha sido dada una fuerza mesiánica sobre la que el pasado exige derechos. No se debe despachar esta exigencia a la ligera" (BENJAMIN, 1973: tesis II). El aporte de retóricas efectistas no es más que el delirio barroco de lo que se quiere mostrar pero que nunca fue. Estos procedimientos apisonan cualquier alternativa a un discurso hegemónico establecido.

El patrimonio heredado no hace distinciones entre los grandes acontecimientos y los pequeños. Simplemente los asume y los deja plasmados en una realidad material que hemos recibido y que debería trascendernos. Bajo este principio, hablar de patrimonio cultural es aplicar un concepto unitario que dilapida cualquier elemento que se salga del discurso establecido. Así, proteger un ámbito de ciudad bajo unos presupuestos concretos puede lle- 


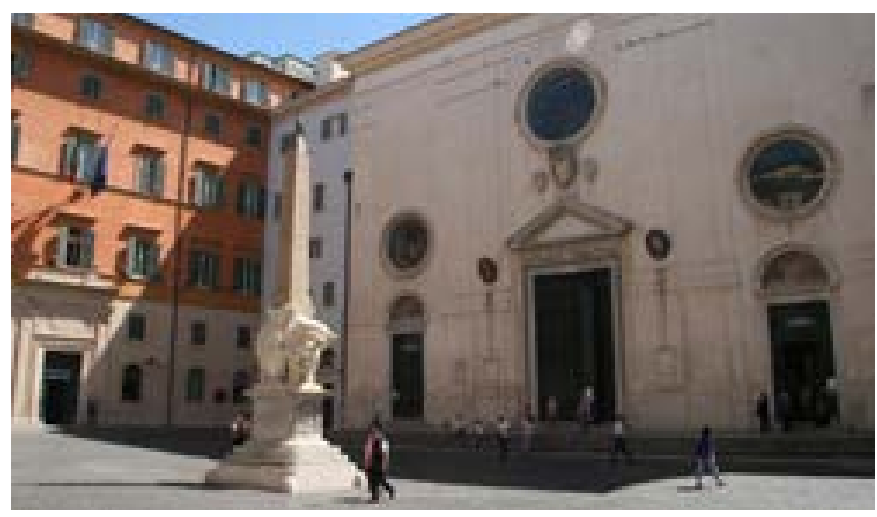

Plaza de la Minerva, Roma | foto Peter Carr

gar a formar parte del discurso monumentalista de la protección de elementos concretos ajenos al contexto.

Si apelamos a la tesis décima de la Filosofía de la Historia de Walter Benjamin, en la que subraya la importancia de la desconfianza del valor que otorgan las masas, tendríamos que replantear nuestros conceptos de patrimonio cultural y los sistemas de valoración y delimitación de las zonas protegidas de la ciudad que están pensadas exclusivamente para el visitante. Prueba de este hecho es la paralela repercusión económica que impacta en las ciudades que contienen un fragmento protegido.

Hace unos meses nos sorprendía la noticia de que unos vándalos habían dejado mellado el elefante ubicado en la Piazza della Minerva de Roma, un monumento barroco encargado por Alejandro VII a Bernini para ubicar sobre él uno de los obeliscos que salpican la ciudad. Toda la prensa se hacía eco de este altercado, aunque lo que realmente sorprendía era el impacto mediático causado. ¿Por qué es noticia que una de las plazas más concurridas de Roma se deteriore? Porque las plazas de nuestras ciudades históricas ya no son lugares urbanos como subraya Innerarity, son nuevas salas de museo. $Y$ ahí radica la sorpresa (INNERARITY, 2006).

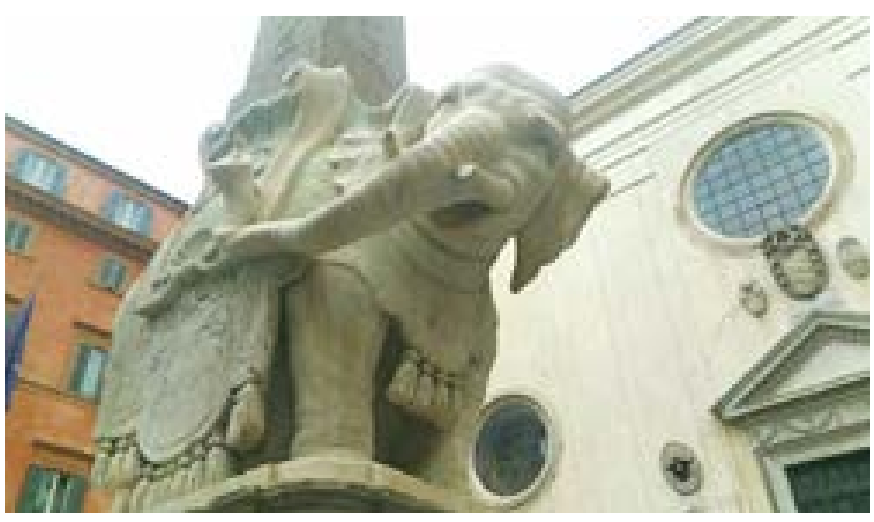

Elefante de Bernini tras la mutilación. Plaza de la Minerva, Roma | foto Nathalie Naim

\section{BIBLIOGRAFÍA}

- Benjamin, W. (1973) Tesis de Filosofía de la Historia. 1. ${ }^{a}$ edición 1940. Madrid: Taurus, 1973, tesis II

- BRINCKERHOFF JACKSON, J. (2012) La necesidad de ruinas $y$ otros ensayos. Santiago de Chile: Ediciones ARQ, 2012

- INNERARITY, D. (2006) El nuevo espacio público. Madrid: Espasa Ediciones, 2006 